\title{
PENGARUH FAKTOR KARAKTERISTIK DEMOGRAFI TERHADAP BIAYA PROYEK INFRASTRUKTUR DESA TERTINGGAL
}

\author{
Pieter Geni $^{1}$ dan Basuki Anondho \\ ${ }^{1}$ Program Studi Sarjana Teknik Sipil, Universitas Tarumanagara, Jl. Letjen S. Parman No.1 Jakarta \\ pieter.325150155@stu.untar.ac.id \\ ${ }^{2}$ Program Studi Sarjana Teknik Sipil, Universitas Tarumanagara, Jl. Letjen S. Parman No.1 Jakarta \\ basukia@ft.untar.ac.id
}

Masuk: 17-01-2020, revisi: 17-02-2020, diterima untuk diterbitkan: 19-02-2020

\begin{abstract}
According to the PDTu Strategic Plan, one of the factors affecting project in disadvantaged villages is the demographic characteristic factor in the region. These factors surely affect the cost of construction projects. Therefore, this study will analyze how much influence the characteristics of demographic characteristics have on project costs in disadvantaged villages. The study was conducted by collecting demographic characteristics data from BPS and cost of the road projects in the border area that had been converted in cost / km. Analysis of the data in this study using the SPSS program. The analysis begin with classical assumption test (normality and heterokedasticity test) and multiple linear regression test analysis ( $F$ test, $t$ test and $R^{2}$ calculation). Based on the $F$ test and $R^{2}$ calculation, the factors of demographic characteristics have a simultaneous influence and of $66.4 \%$ on the cost of underdeveloped village projects. But in the t test, only location and urbanization factors partially affect project costs. Therefor, new model of that 2 variable is needed. Based on the newest model, it can be concluded that the two variables have simultaneous influence and as much as $60.6 \%$ on the project costs. Geographical difficulty index factor is the most influential factor.
\end{abstract}

Keywords: dominant demographic characteristic factors; project costs; backward village

\begin{abstract}
ABSTRAK
Menurut Rencana Strategis PDTu, salah satu faktor yang mempengaruhi pelaksanaan proyek di desa tertinggal merupakan faktor karakteristik demografi di wilayah tersebut. Faktor-faktor tersebut juga tentu mempengaruhi biaya proyek konstruksinya. Oleh karena itu, penelitian ini akan menganalisa seberapa besar pengaruh faktorfaktor karakteristik demografi terhadap biaya proyek di desa tertinggal. Penelitian dilakukan dengan mengumpulkan data-data karakteristik demografi dari badan pusat statistik serta data biaya proyek jalan di daerah perbatasan yang telah dikonversi dalam biaya $/ \mathrm{km}$. Analisis data pada penelitian ini menggunakan program SPSS. Analisis dilakukan dengan uji asumsi klasik (uji normalitas dan heterokedastisitas) dan analisis uji regresi linear berganda (uji $\mathrm{F}$, $\mathrm{t}$ dan perhitungan $\mathrm{R}^{2}$ ). Berdasarkan uji $\mathrm{F}$ dan perhitungan $\mathrm{R}^{2}$, faktor- faktor karakteristik demografi mempunyai pengaruh secara simultan dan sebesar $66.4 \%$ terhadap biaya proyek desa tertinggal. Namun dalam uji t, hanya faktor lokasi dan urbanisasi yang mempengaruhi biaya proyek secara parsial. Sehingga dilakukan uji $\mathrm{F}$, $\mathrm{t}$ dan perhitungan $\mathrm{R}^{2}$ untuk 2 variabel untuk mendapatkan model yang baru. Berdasarkan model terbaru, dapat disimpulkan bahwa kedua variabel mempunyai pengaruh secara simultan dan sebesar $60.6 \%$ terhadap biaya proyek. Faktor indeks kesulitan geografis menjadi faktor yang paling berpengaruh.
\end{abstract}

Kata kunci: faktor karakteristik demografi dominan; biaya proyek; desa tertinggal

\section{PENDAHULUAN}

Pembangunan infrastruktur daerah tertinggal merupakan salah satu agenda pemerintah dalam upaya pemerataan ekonomi dan kualitas hidup di seluruh Indonesia.Namun dalam pelaksanaannya Ditjen PDTU mengalami kesulitan dan hambatan. Menurut Rencana Strategis PDTu (Renstra PDTu) tahun 2016-2019, terdapat isu strategis yang menjadi pokok permasalahan yaitu belum efektifnya pelaksanaan kebijakan dalam pengembangan daerah perbatasan, daerah pulau kecil dan terluar antara lain karena faktor demografi di wilayah tersebut. Belum optimalnya pengembangan perekonomian wilayah berbasis potensi sumber daya lokal akibat masih rendahnya 
produktivitas masayarakat, ketersediaan modal rendah, serta rendahnya aksesbilitas daerah tertinggal menjadi faktor yang mempengaruhi pembangunan daerah tertinggal, khususnya daerah perbatasan. Oleh sebab itu pembangunan infrastruktur desa tertinggal juga harus memperhatikan faktor demografi di wilayah tersebut.

Masalah lokal dan lingkungan di pedesaan berpengaruh terhadap metode pelaksanaan konstruksinya. Tantangan dalam pelaksanaan proyek merupakan dampak dari masalah sosial-ekonomi serta isu lingkungan di pedesaan. (Tran, et al, 2015). Hal ini menunjukkan bahwa masalah sosial-ekonomi dan isu lingkungan di suatu wilayah pedesaan atau kondisi demografi setempat mempengaruhi pelaksanaan konstruksinya. Beberapa faktor karakteristik demografi tersebut antara lain lokasi, usia, tingkat pendidikan, pengalaman, jenis kelamin,tenaga kerja, dan urbanisasi.

Paparan diatas menunjukkan faktor sumber daya manusia merupakan salah satu faktor demografi yang dapat mempengaruhi kinerja proyek. Pengelompokkan karakteristik demografi membantu pelaku penyedia jasa konstruksi mempertimbangakan halangan atau kemudahan dalam proyek di suatu daerah, terutama di bidang sumber daya manusia (tenaga kerja). Kinerja suatu proyek berkaitan dan berhubungan dengan banyak hal dan faktor, salah satunya adalah biaya proyek (Abushaban, 2008). Dengan melihat pentingnya faktor karakteristik demografi dalam pelaksanaan proyek infrastruktur di pedesaan dan biaya proyek yang menjadi unsur penting dalam proyek maka tujuan dari penelitian ini adalah untuk mengetahui besar pengaruh faktor karakteristik demografi dominan terhadap biaya proyek infrastruktur desa tertinggal di Indonesia.

\section{Demografi}

Demografi merupakan ilmu yang mempelajari perubahan kependudukan mengenai perubahan jumlah, persebaran dan komposisi atau struktur penduduk. Perubahan tersebut dipengaruhi oleh perubahan pada komponen utama pertumbuhan penduduk yaitu, fertilitas, mortalitas dan migrasi. Secara menyeluruh demografi memberi gambaran tentang perilaku penduduk, baik secara agregat maupun kelompok (Yasin \& Adiotomo, 2010). Menurut Sumarsono (2008), Karakteristik demografi menjadi dasar pengelompokan komposisi penduduk dalam ilmu demografi. Pengelompokan karakteristik tersebut anatar lain adalah menurut demografi, social, ekonomi, dan geografis. Data kependudukan harus dikaji secara akurat agar mempermudah pembangunan dan pelaksanaan proyek dilakukan dengan rencana yang tepat. Berdasarkan penelitian terdahulu, yang dihasilkan dari studi jurnal American Society of Civil Engineers (ASCE), faktor karakteristik demografi yang mempengaruhi pelaksanaan proyek adalah lokasi, pengalaman, usia, tingkat pendidikan, tingkat penghasilan, jenis kelamin, urbanisasi dan tenaga kerja.

\section{Biaya Proyek}

Menurut Remi (2017), dalam suatu proyek konstruksi diperlukan 2 jenis biaya yang menunjang berjalannya pelaksanaan proyek konstruksi tersebut. Biaya tersebut dikelompokan dalam 2 kelompok besar yaitu biaya langsung (Direct cost) dan biaya tak langsung (Indirect Cost). Dalam tahap akhir proyek kedua kelompok biaya tersebut digabung menjadi satu menjadi biaya akhir proyek. Biaya langsung merupakan seluruh biaya yang berkaitan dengan fisik proyek, yaitu terdiri dari biaya dari kegiatan proyek dari awal sampai akhir serta biaya suber daya yang digunakan dalam pelaksanaan proyek yang meliputi sumber daya manusia, material, alat, dan sub kontarktor. Selain itu biaya overhead yang meliputi upah tenaga kerja, biaya administrasi, dan segala hal yang berkaitan dengan jalannya proyek juga termasuk biaya langsung. Sementara itu biaya tak langsung (indirect cost) dalam proyek merupakan biaya yang tidak berkaitan langsung dengan fisik proyek, melainkan hal yang mendukung pekerjaan proyek konstruksi. Besar atau kecilnya biaya tak langsung diperngaruhi seiring berjalannya proyek konstruksi yang bersangkutan. Oleh karena itu biaya tak langsung kerap menjadi kendalan bagi kontraktor dalam mendukung pekerjaan proyek.

\section{METODE PENELITIAN}

\section{Pengumpulan Data Faktor Karakteristik Demografi dan Biaya Proyek}

Penelitian dimulai dengan mengumpulkan data indikator yang mewakili variabel karakteristik demografi dominan yang diambil dari penelitian terdahulu serta data biaya proyek. Dalam penelitian ini, data demografi diperoleh dari website Badan Pusat Statistik yaitu bps.go.id. Sementara itu, data biaya proyek diperoleh dari data proyek pembangunan jalan daerah perbatasan oleh Direktorat Pengembangan Daerah Perbatasan. 
Tabel 1. Faktor karakteristik demografi dominan

\begin{tabular}{cc}
\hline $\begin{array}{c}\text { Faktor } \\
\text { Karakterisitik } \\
\text { Demografi } \\
\text { Dominan }\end{array}$ & Indikator \\
\hline Usia & \\
Lokasi & Jumlah penduduk usia angkatan kerja \\
Tenaga Kerja & Indeks kesulitan geografis (IKG) \\
Pengalaman & Jumlah pekerja tenaga ahli konstruksi \\
Jenis Kelamin & Jumlah tenaga kerja terampil berpengalaman dengan \\
Urbanisasi & sertifikasi \\
Tingkat Pendidikan & Angka partisipasi wanita sebagai tenaga professional \\
& Jumlah penduduk migrasi masuk \\
Rasio angka partisipasi sekolah (APS)
\end{tabular}

Tahap selajutnya adalah mengumpulkan data biaya proyek jalan raya sebagai variabel terikat, yang diperoleh dari Direktorat Pengembangan Daerah Perbatasan tahun 2015-2018. Setelah itu, data biaya proyek tersebut dikonversi menurut kurs dollar yang berlaku pada tahun 2018 dengan menggunakan rumus:

$$
\text { Biaya Konversi }=\frac{\text { Biaya Tahunn }}{\text { Willai USD Tahun } n} \times \text { Nilai USD Tahun } 2018
$$

Kemudian biaya yang telah dikonversi diubah menjadi harga/km dengan membagi harga total proyek dengan volume proyek Data biaya/km digunakan sebagai variable terikat. Untuk mencari biaya/km digunakan rumus berikut:

$$
\text { Biaya } / \mathrm{km}=\frac{\text { Biaya Konversi }}{\text { Volume Peherjann }}
$$

\section{Uji asumsi klasik}

Mengingat data penelitian yang digunakan adalah sekunder, maka untuk memenuhi syarat yang ditentukan sebelum uji hipotesis melalui uji $\mathrm{F}$ maka perlu dilakukan pengujian atas beberapa asumsi klasik yang digunakan yaitu normalitas dan heteroskedastisitas. Pengujian normalitas data menggunakan Test of Normality KolmogorovSmirnov dalam program SPSS. Dasar pengambilan keputusan dalam Test of Normality Kolmogorov-Smirnov bisa dilakukan berdasarkan probabilitas (Asymtotic Significance), yaitu:

a) Jika probabilitas $>0,05$ maka distribusi dari model regresi adalah normal.

b) Jika probabilitas $<0,05$ maka distribusi dari model regresi adalah tidak normal.

Sementara itu, untuk menguji ada tidaknya heteroskedastisitas akan dilakukan metode melihat grafik scatterplot pada program SPSS. Metode ini dilakukan dengan cara melihat grafik scatterplot antara standardized predicted value (ZPRED) dengan studentized residual (SRESID). Dasar pengambilan keputusan pada metodeo ini adalah sebagai berikut:

a) Jika ada pola tertentu, seperti titik-titik yang ada membentuk suatu pola tertentu yang teratur (bergelombang, melebar kemudian menyempit), maka terjadi gejala heteroskedastisitas.

b) Jika tidak ada pola yang jelas, seperti titik-titik menyebar di atas dan di bawah angka 0 pada sumbu $\mathrm{Y}$, maka tidak terjadi heteroskedastisitas.

\section{Analisis regresi linear berganda}

Setelah data diuji dengan uji normalitas dan uji heterokedastisitas pada uji asumsi klasik, maka data dinyatakan layak untuk dianalisis secara regresi linear berganda. Pada penelitian ini dilakukan analisis regresi linear berganda karena terdapat 7 variabel bebas faktor karakteristik demografi yang akan dianalisis pengaruhnya terhadap variabel terikat yaitu biaya proyek desa tertinggal. Pada penelitian ini analisis regresi linear berganda meliputi uji F, uji t dan perhitungan koefisien determinasi.

\section{HASIL DAN PEMBAHASAN}

Setelah melalui proses pengambilan data, maka sampel pada penelitian ini adalah 40 proyek pembangunan jalan daerah perbatasan tahun 2015-2018 di Indonesia. Data Biaya proyek dikonversi sesuai dengan kurs US dollar pada 
tahun 2018 dan diubah dalam satuan biaya/km. Selanjutnya data indikator faktor karakteristik demografi disesuaikan menurut provinsi dan tahun proyek berlangsung.

\section{Uji normalitas}

Uji normalitas dilakukan dengan menggunakan uji Kolmogorov-Smirnov. Hasil pengujian dengan SPSS dapat dilihat pada tabel 2 berikut.

Tabel 2. Hasil Uji Normalitas

One-Sample Kolmogorov-Smirnov Test

\begin{tabular}{llr}
\multicolumn{2}{c}{ One-Sample Kolmogorov-Smirnov Test } \\
\hline & & $\begin{array}{c}\text { Unstandardized } \\
\text { Residual }\end{array}$ \\
\hline $\mathrm{N}$ & Mean & 40 \\
Normal Parameters ${ }^{\mathrm{a}, \mathrm{b}}$ & Std. Deviation & .0000000 \\
& Absolute & .126 \\
Most Extreme Differences & Positive & .074 \\
& Negative & -.126 \\
& & .126 \\
Test Statistic & & $.110^{c}$ \\
\hline Asymp. Sig. (2-tailed) & & \\
& & \\
\hline
\end{tabular}

Dari tabel tersebut dapat dilihat bahwa nilai sig. pada uji Kolmogorov-Smirnov $>0.05$. Hal ini menunjukan bahwa data penelitian terdistribusi secara normal.

\section{Uji heterokedastisitas}

Uji heterokedastisitas pada penelitian dilakukan dengan melihat hasil grafik scatter plot yang dihasilkan. Hasil uji heterokedastisitas dapat dilihat pada gambar 1.

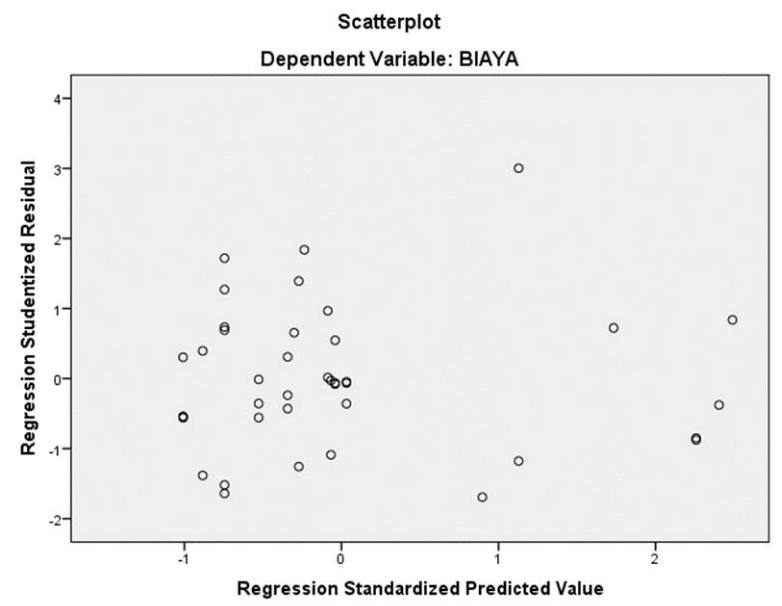

Gambar 1. Hasil Uji Heterokedastisitas

Dari grafik tersebut dapat dilihat bahwa data tidak menunjukan gejala heterokedastisitas yaitu grafik tidak membentuk pola serta data tersebar di atas dan di bawah garis 0 .

\section{Uji signifikansi simultan (uji F) 7 variabel}

Uji F dilakukan untuk mengetahui apakah 7 variabel factor karakteristik demografi dominan berpengaruh secara simultan terhadap biaya proyek. Hasil dari uji F dapat dilihat pada tabel 3. 
Tabel 3. Hasil Uji Signifikansi Simultan (Uji F) 7 Variabel

\begin{tabular}{|c|c|c|c|c|c|c|}
\hline \multicolumn{7}{|c|}{ ANOVA $^{a}$} \\
\hline & Model & Sum of Squares & $\mathrm{df}$ & Mean Square & $\mathrm{F}$ & Sig. \\
\hline \multirow[t]{6}{*}{1} & Regression & 7407460550245 & \multirow{2}{*}{7} & 1058208650035 & \multirow{4}{*}{11.082} & \multirow{2}{*}{$.000^{\mathrm{b}}$} \\
\hline & & 455900.000 & & 065090.000 & & \\
\hline & Residual & 3055679073459 & \multirow{2}{*}{32} & 9548997104561 & & \\
\hline & & 562500.000 & & 1328.000 & & \\
\hline & \multirow[t]{2}{*}{ Total } & 1046313962370 & \multirow{2}{*}{39} & & & \\
\hline & & 5018000.000 & & & & \\
\hline
\end{tabular}

Dari tabel tersebut, maka hipotesis pada penelitian ini dapat dijawab sebagi berikut

- $\mathrm{H}_{0} \quad$ : Tidak ada pengaruh antara faktor-faktor karakteristik demografi dominan terhadap biaya proyek secara signifikan

- $\mathrm{H}_{1} \quad$ : Ada pengaruh antara faktor-faktor karakteristik demografi dominan terhadap biaya proyek secara siginifikan

Dari tabel $\mathrm{F}$ dengan $\mathrm{df}_{1}=\mathrm{k}-1=8-1=6 \mathrm{dan}_{\mathrm{df}}=\mathrm{n}-\mathrm{k}=40-8=32$ (taraf signifikansi 5\%), didapat nilai $\mathrm{F}$ tabel $=$ 2.40. $\mathrm{F}$ hitung didapat sebesar $11.082>\mathrm{F}$ tabel (Sig.<0,05), hal ini membuktikan bahwa $\mathrm{H}_{0}$ ditolak sehingga dapat disimpulkan bahwa faktor-faktor demografi dominan mempunyai pengaruh yang simultan terhadap biaya proyek pedesaan di Indonesia.

\section{Perhitungan koefisien determinasi 7 variabel}

Uji koefisen determinasi digunakan untuk melihat besar pengaruh faktor-faktor karakteristik dominan terhadap biaya proyek. Besar pengaruh faktor-faktor tersebut dapat dilihat pada nilai adjusted R square pada tabel 4 .

Tabel 4. Hasil Uji Koefisien Determinasi 7 Variabel

\begin{tabular}{ccccc}
\multicolumn{5}{c}{ Model Summary $^{\mathbf{b}}$} \\
\hline Model & $\mathrm{R}$ & R Square & $\begin{array}{c}\text { Adjusted R } \\
\text { Square }\end{array}$ & $\begin{array}{c}\text { Std. Error of the } \\
\text { Estimate }\end{array}$ \\
\hline 1 & & & & \\
& $.841^{\mathrm{a}}$ & .708 & .644 & 309014515.91408 \\
\hline
\end{tabular}

Berdasarkan tabel diatas, dapat diketahui nilai adjusted $R$ square pada analisis ini adalah 0.644 (66.4\%). Hasil ini menunjukan bahwa biaya proyek pedesaan di Indonesia dipengaruhi oleh faktor demografi sebesar $66.4 \%$. Sementara itu 33.6\% dipengaruhi oleh variabel-variabel lainnya.

\section{Uji signifikansi parsial (uji t) 7 variabel}

Uji t dilakukan untuk mengetahui apakah faktor-faktor demografi dominan berpengaruh secara parsial terhadap biaya proyek pedesaan. Hasil dari uji t dapat dilihat pada tabel 5. 
Tabel 5. Nilai Koefisien 7 Variabel

Coefficients $^{\mathrm{a}}$

\begin{tabular}{|c|c|c|c|c|c|c|c|}
\hline \multirow[b]{2}{*}{ Model } & \multicolumn{2}{|c|}{ Unstandardized Coefficients } & \multirow[b]{2}{*}{ Beta } & \multirow[b]{2}{*}{$\mathrm{t}$} & \multicolumn{3}{|c|}{$\begin{array}{c}\text { Collinearity } \\
\text { Statistics }\end{array}$} \\
\hline & $\mathrm{B}$ & Std. Error & & & Sig. & $\begin{array}{c}\text { Tolera } \\
\text { nce }\end{array}$ & VIF \\
\hline (Constant) & -6142284263.113 & 2842615345.949 & & -2.161 & .038 & & \\
\hline $\mathrm{X} 1$ & 474.334 & 289.711 & .666 & 1.637 & .111 & .055 & 18.130 \\
\hline $\mathrm{X} 2$ & 52513331.051 & 20663199.278 & .849 & 2.541 & .016 & .082 & 12.232 \\
\hline $\mathrm{X} 3$ & 102633.015 & 85435.187 & .208 & 1.201 & .238 & .306 & 3.270 \\
\hline $\mathrm{X} 4$ & -54122.326 & 32538.368 & -.341 & -1.663 & .106 & .218 & 4.592 \\
\hline $\mathrm{X} 5$ & 87916233.161 & 43797014.271 & .857 & 2.007 & .053 & .050 & 19.958 \\
\hline X6 & -9038.874 & 3414.976 & -1.101 & -2.647 & .012 & .053 & 18.965 \\
\hline $\mathrm{X} 7$ & 44943041.242 & 32853544.253 & .477 & 1.368 & .181 & .075 & 13.318 \\
\hline
\end{tabular}

Dari tabel $\mathrm{t}$ dengan $\mathrm{df}=\mathrm{n}-\mathrm{k}=40-8=32$ (taraf signifikansi 5\%), didapat nilai $\mathrm{t}$ tabel $=2.0369$. Dari hasil $\mathrm{t}$ hitung ketujuh variabel, hanya nilai t hitung X2 dan X6 yang lebih besar dari t table, yaitu masing senilai 2.541 dan 2.647. Sehingga dilakukan uji F, uji t dan perhitungan koefisien determinasi pada kedua variabel tersebut.

\section{Uji signifikansi simultan (uji F) 2 variabel}

Uji F dilakukan untuk mengetahui apakah indeks kesulitan geografis dan jumlah penduduk migrasi keluar berpengaruh secara simultan terhadap biaya proyek. Hasil dari uji F dapat dilihat pada tabel 6.

Tabel 6. Hasil Uji Signifikansi Simultan (Uji F) 2 Variabel

\begin{tabular}{|c|c|c|c|c|c|c|}
\hline \multicolumn{7}{|c|}{ ANOVA $^{\mathbf{a}}$} \\
\hline Model & & Sum of Squares & df & Mean Square & $\mathrm{F}$ & Sig. \\
\hline \multirow{6}{*}{1} & & 65557143466162 & \multirow{2}{*}{2} & 32778571733081 & \multirow{4}{*}{31.039} & \multirow{2}{*}{$.000^{\mathrm{b}}$} \\
\hline & 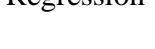 & 62700.000 & & 31300.000 & & \\
\hline & & 39074252770887 & \multirow{2}{*}{37} & 10560608856996 & & \\
\hline & Kestatar & 55200.000 & & 6352.000 & & \\
\hline & Total & 10463139623705 & \multirow{2}{*}{39} & & & \\
\hline & 10tai & 018000.000 & & & & \\
\hline
\end{tabular}

Dari tabel tersebut, maka hipotesis pada penelitian ini dapat dijawab sebagi berikut

- $\mathrm{H}_{0} \quad$ : Tidak ada pengaruh antara faktor-faktor karakteristik demografi dominan terhadap biaya proyek secara signifikan

- $\mathrm{H}_{1} \quad$ : Ada pengaruh antara faktor-faktor karakteristik demografi dominan terhadap biaya proyek secara siginifikan

Dari tabel $\mathrm{F}$ dengan $\mathrm{df}_{1}=\mathrm{k}-1=3-1=2$ dan $\mathrm{df}_{2}=\mathrm{n}-\mathrm{k}=40-3=37$ (taraf signifikansi $5 \%$ ), didapat nilai $\mathrm{F}$ tabel = 3.25. F hitung didapat sebesar $31.039>\mathrm{F}$ tabel (Sig.<0,05), hal ini membuktikan bahwa $\mathrm{H}_{0}$ ditolak sehingga dapat disimpulkan bahwa indeks kesulitan geografis dan jumlah penduduk migrasi keluar mempunyai pengaruh yang simultan terhadap biaya proyek pedesaan di Indonesia. 


\section{Perhitungan koefisien determinasi 2 variabel}

Uji koefisen determinasi digunakan untuk melihat besar pengaruh variabel X2 dan X6 terhadap biaya proyek. Besar pengaruh kedua faktor tersebut dapat dilihat pada nilai adjusted R square pada table 7 .

Tabel 7. Hasil Uji Koefisien Determinasi 2 Variabel

\begin{tabular}{|c|c|c|c|c|}
\hline \multicolumn{5}{|c|}{ Model Summary ${ }^{b}$} \\
\hline & & & Adjusted R & Std. Error of the \\
\hline Model & $\mathrm{R}$ & R Square & Square & Estimate \\
\hline 1 & $.792^{\mathrm{a}}$ & .627 & .606 & 324970904.18985 \\
\hline
\end{tabular}

Berdasarkan tabel diatas, dapat diketahui nilai adjusted $R$ square pada analisis ini adalah 0.606 (60.6\%). Hasil ini menunjukan bahwa biaya proyek pedesaan di Indonesia dipengaruhi oleh indeks kesulitan geografis dan jumlah penduduk migrasi keluar sebesar $60.6 \%$. Sementara itu 39.4\% dipengaruhi oleh variabel-variabel lainnya.

\section{Uji signifikansi parsial (uji t) 2 variabel}

Uji t dilakukan untuk mengetahui apakah faktor-faktor demografi dominan berpengaruh secara parsial terhadap biaya proyek pedesaan. Hasil dari uji t dapat dilihat pada tabel 8 .

Tabel 8. Nilai Koefisien 2 Variabel

Coefficients $^{\mathrm{a}}$

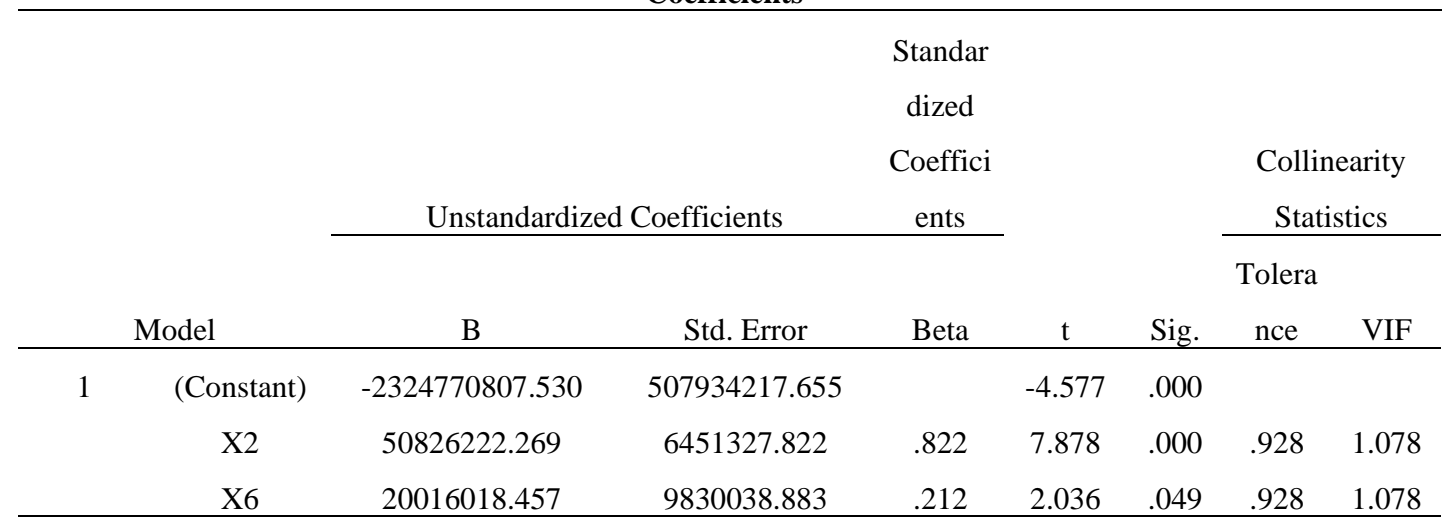

Berdasarkan tabel tersebut, maka hipotesis dapat dijawab sebagai berikut:

\section{a. Hipotesis Pertama}

$\mathrm{H}_{0} \quad$ : Tidak ada pengaruh indeks kesulitan geografis terhadap biaya proyek secara signifikan

$\mathrm{H}_{1} \quad$ : Ada pengaruh indeks kesulitan geografis terhadap biaya proyek secara signifikan

Dari tabel $\mathrm{t}$ dengan $\mathrm{df}=\mathrm{n}-\mathrm{k}=40-3=37$ dan taraf signifikansi 5\%, didapat nilai t tabel $=1.687$. Motivasi kerja memiliki thitung sebesar $7.878<\mathrm{t}$ tabel (Sig. $<0,05$ ). Hal ini membuktikan bahwa $\mathrm{H}_{0}$ diterima sehingga disimpulkan bahwa indeks kesulitan geografis mempunyai pengaruh yang signifikan terhadap biaya proyek.

b. Hipotesis Kedua

$\mathrm{H}_{0} \quad$ : Tidak ada pengaruh jumlah penduduk migrasi keluar terhadap biaya proyek secara signifikan

$\mathrm{H}_{1} \quad$ : Ada pengaruh pengaruh jumlah penduduk migrasi keluar terhadap biaya proyek secara signifikan

Dari tabel $\mathrm{t}$ dengan $\mathrm{df}=\mathrm{n}-\mathrm{k}=40-3=37$ dan taraf signifikansi $5 \%$, didapat nilai $\mathrm{t}$ tabel $=1.687$. Motivasi kerja memiliki t hitung sebesar $2.036>\mathrm{t}$ tabel (Sig. $<0,05$ ). Hal ini membuktikan bahwa $\mathrm{H}_{1}$ diterima sehingga disimpulkan bahwa jumlah penduduk migrasi keluar mempunyai pengaruh yang signifikan terhadap biaya proyek.

\section{Model persamaan regresi 2 variabel}

Dari hasil analisis, didapatkan hasil koefisien yang dimuat dalam tabel 4.16. Berdasarkan tabel tersebut, maka terbentuk persamaan regresi sebagai berikut: 
Dimana:

Y

$\mathrm{X} 2$

$\mathrm{X} 6$
$=$ Data biaya proyek jalan per $\mathrm{km}$

= Indeks kesulitan geografis (IKG)

= Jumlah penduduk migrasi keluar

Keterangan:

a. Y menyatakan biaya proyek / km .

b. Konstanta $=2324770808$ menyatakan nilai biaya bila seluruh nilai variabel bebas adalah nol

c. Koefisien X2 bernilai 5082622227, artinya setiap jika variabel lain tetap dan nilai X2 (indeks kesulitan geografis) bertambah 1 satuan, maka nilai biaya akan naik sebesar 5082622227.

d. Koefisien X6 bernilai 20016018, artinya setiap jika variabel lain tetap dan nilai X6 (jumlah penduduk migrasi keluar) bertambah 1 satuan, maka nilai biaya akan naik sebesar 20016018.

\section{KESIMPULAN DAN SARAN}

\section{Kesimpulan}

Berdasarkan hasil analisis yang dilakukan pada bab 4, maka dapat ditarik kesimpulan sebagai berikut:

1. Beberapa faktor karakteristik demografi sebagai faktor eksternal mempunyai pengaruh terhadap biaya proyek desa tertinggal di Indonesia. Faktor karakteristik demografi tersebut adalah indeks kesulitan geografis dan jumlah penduduk migrasi keluar di wilayah tersebut.

2. Berdasarkan analisis, dari ketujuh faktor pengaruh karakteristik demografi, hanya faktor kesulitan geografis dan tingkat urbanisasi yang secara kesatuan dapat dijadikan model faktor pengaruh.

3. Faktor kesulitan geografis pada lokasi proyek merupakan faktor yang lebih mempengaruhi penentuan biaya proyek konstruksi pedesaan.

\section{Saran}

Berdasarkan hasil analisis data dan kesimpulan, maka saran yang dapat diberikan adalah sebagai berikut:

1. Faktor-faktor karakteristik demografi pada hasil penelitian diatas dapat menjadi hal yg dapat dipertimbangkan dalam penentuan alokasi dana bantuan pemerintah untuk desa tertinggal.

2. Penelitian selanjutnya diharapkan dapat mengembangkan variabel demografi lain yang belum dianalisis pada penelitan ini untuk melihat pengaruhnya terhadap biaya proyek. Sehingga penentuan alokasi dana bantuan pemerintah untuk proyek konstruksi pedesaan dapat dijalankan secara maksimal.

3. Proyek konstruksi pedesaan yang diteliti adalah proyek jalan pada daerah perbatasan. Pada penelitian selanjutnya diharapkan dapat diteliti pula kegiatan konstruksi lainnya.

\section{DAFTAR PUSTAKA}

Abushaban, S. S. "Factors Affecting the Performance of Construction Projects in The Gaza Strip". Thesis The Islamic University of Gaza Construction Management, 2008.

Direktorat Jenderal Pengembangan Daerah Tertentu. Review Rencana Strategis Ditjen PDTu 2015-2019. 27 September 2018.

Remi, Fahadilla. "Kajian Faktor Penyebab Cost Overrun pada Proyek Konstruksi Gedung”. Jurnal Teknik Mesin Universitas Katolik Parahyangan, Edisi Spesial Vol. 06, 2017, 10.22441/jtm.v6i2.1187

Sumarsono, S. Ekonomi manajemen sumberdaya manusia dan ketenagakerjaan. Graha Ilmu Semarang, 2008.

Tran, D.Q., et al. "Construction Management Challenges and Best Practices for Rural Transit Projects". ASCE: Journal of Management in Engineering, 31(5), 2015, doi: 10.1061.

Yasin, M. and Adioetomo, S. M. Demografi: Arti dan Tujuan. Edisi 2, Salemba Empat Jakarta, 2010. 